\title{
Stability of Underground Coal Mine Roadway Excavated in Soft Rock Mass
}

\author{
Phanthoudeth Pongpanya, Vongsavanh Soysouvanh, Takashi Sasaoka, and Hideki Shimada
}

\begin{abstract}
This paper studies the stability and ground behavior of the main roadway excavated in a soft rock mass at PT Gerbang Daya Mandiri (GDM) underground coal mine in Indonesia. The stability and ground behavior of the main roadway under various geological and excavation conditions was analyzed and discussed through numerical simulations and field measurement data. Based on the results, it is found that the mechanical conditions of claystone and the geological conditions of the roof have an obvious impact on the stability of the main roadway. The large roof displacement of the roadway occurs when the roadway is excavated in the deteriorated claystone, whereas the small roof displacement occurs when the roadway excavation is made in the undeteriorated claystone and when the coal layer is present in the roof. Under undeteriorated conditions of claystone, the small failure zone and displacement of the roadway occur. The current support system using the steel arch SS400 is effective to control the roadway stability. As the claystone has deteriorated due to groundwater, the failure zone and displacement expand considerably, and the roadway stability decreases significantly. The use of the current support system (steel arch SS400) is difficult to control the stability of the main roadway. Under this situation, a stronger steel arch SS540 is recommended to apply. Furthermore, the presence of a coal layer during the excavation considerably improves the stability of the main roadway. Compared with the roadway excavated in claystone only, the displacement decreases significantly. In addition, by leaving a thicker coal layer in the roof, a better stability condition of the roadway can be achieved.
\end{abstract}

Key words - Indonesia, Main Roadway Stability, Underground Coal Mine, Weak Rock.

\section{INTRODUCTION}

In this research, the PT Gerbang Daya Mandiri (GDM) underground coal mine is selected as a representative mine site for the study. The GDM coal mine is one of the underground coal mines and is still in the process of developing the main roadways to access the targeted coal seams. This underground coal mine is situated in Samarinda City, East Kalimantan, Indonesia (Fig. 1). The geological and recoverable sub-bituminous coal reserves of the GDM coal mine are approximately 58.3 million tons and 29.2 million tons, respectively. The annual coal production of 1 million tons is planned to be mined by a longwall mining method during its mine lifetime.

The planned layout of the main roadways and longwall panels of the GDM coal mine is illustrated in Fig. 2. Two main roadways namely North and South Roadway are being excavated by using the road header machine to access the coal seams (Fig. 3). The excavation of main roadways is commenced from the final highwall of the old surface coal mine, and the final highwall height is about $15 \mathrm{~m}$ from the ground surface. The main roadways are designed using a semi-circular shape with $5 \mathrm{~m}$ in width, $3 \mathrm{~m}$ in height, and $6^{\circ}$ dip. The total heading length of each roadway is approximately $350 \mathrm{~m}$ and the overburden thickness above a current excavation face is about $40 \mathrm{~m}$. Main roadways are currently stable at the shallow depth with the occurrence of some cracks and rock mass deformations along the roof and sidewalls.

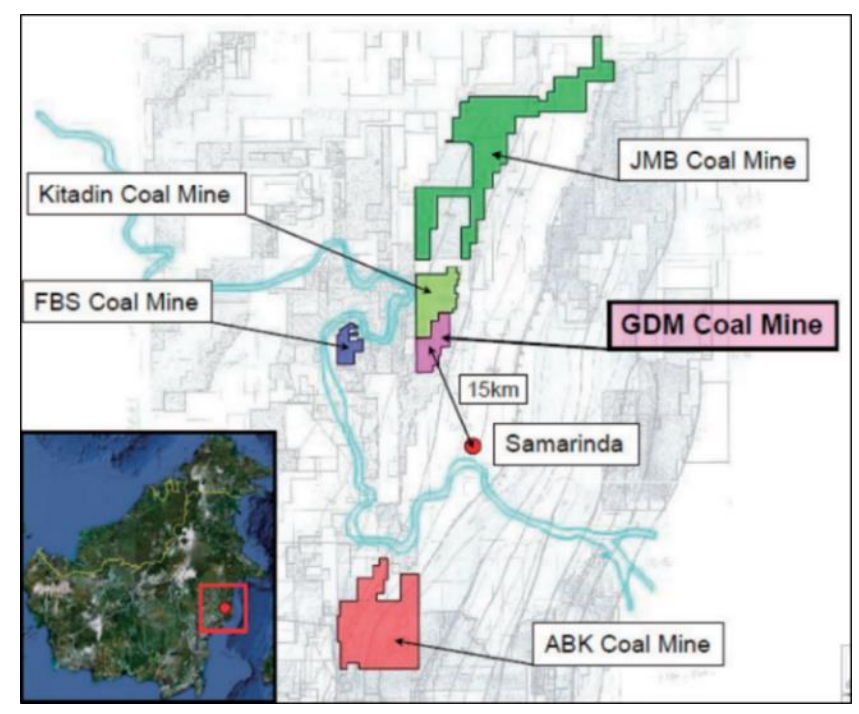

Fig. 1. Location of GDM coal mine.

In the GDM coal mine, the major coal-bearing formations consist of Balikpapan and Pulau Balang Formations (Fig. 4). The rock units of dark to light gray mudstone, dark to brownish-gray sandstone, dark to light gray siltstone and claystone, coal, and coaly shale is found in Balikpapan Formation; while the rock units of dark to light gray mudstone, dark to whitish-gray and brownish-gray sandstone, dark gray to light gray siltstone, coal, and coaly shale are in Pulau Balang Formation. The geological structure of the GDM coal mine is a simple monocline structure, while the fault was not found in the mine area. Several coal seams with the dip ranging from $3^{\circ}$ to $13^{\circ}$, and the thickness varies from $0.15 \mathrm{~m}$ to $9.8 \mathrm{~m}$ are found in the GDM coal mine. The typical stratigraphy of the GDM underground mine is shown in Fig.

Takashi Sasaoka, Kyushu University, Japan.

(e-mail: sasaoka@mine.kyushu-u.ac.jp).

Hideki Shimada, Kyushu University, Japan.

(e-mail: shimada ${ }^{@}$ mine.kyushu-u.ac.jp).

Phanthoudeth Pongpanya, National University of Laos, Laos.

(e-mail: phanthoudeth.p ${ }^{@}$ gmail.com)

Vongsavanh Soysouvanh, National University of Laos, Laos.

(e-mail: vongsoy@gmail.com) 
5. Seam BC and Seam F are two mineable coal seams for this underground coal mine. The thickness of Seam BC thickness is about 3.39-9.80 m, whereas the thickness of Seam F is about $0.70-3.20 \mathrm{~m}$. The coal seams are separated by claystone and sandstone rock layers. However, claystone is found to be a dominant rock unit in this underground coal mine.

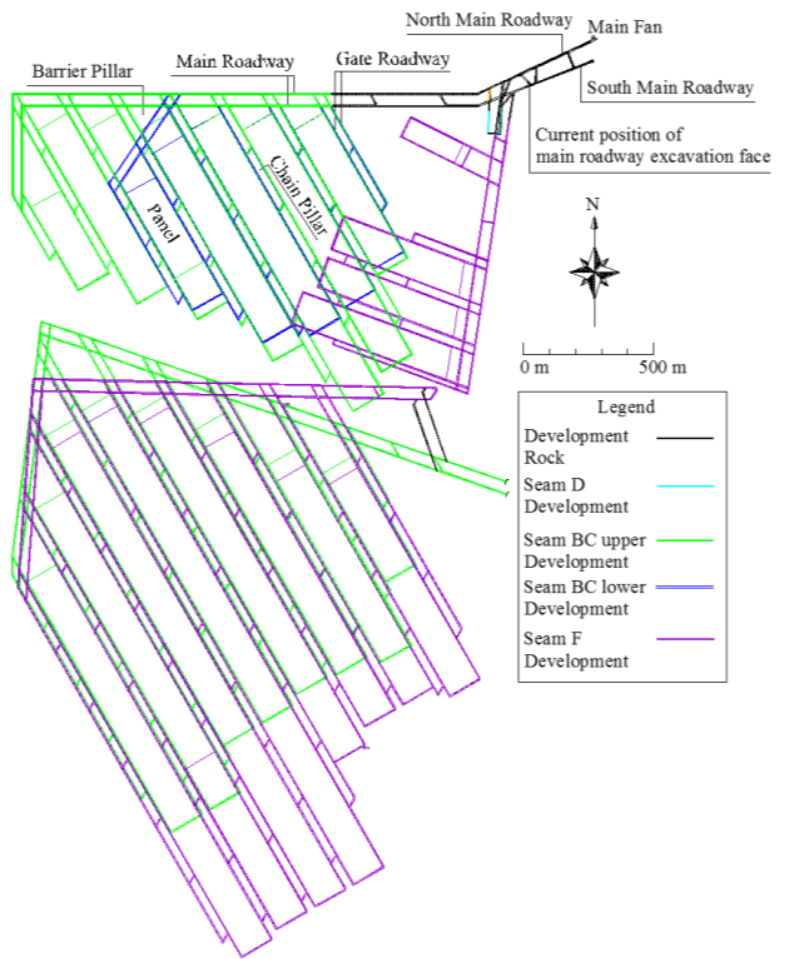

Fig. 2. Mine layout of GDM underground coal mine.

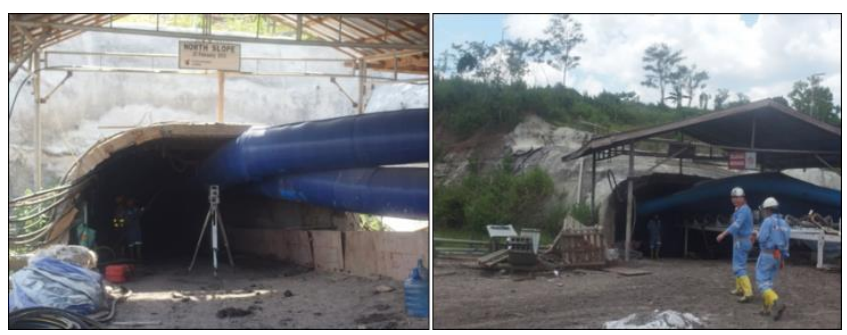

Fig. 3. South Main Roadway of GDM coal mine.

Fig. 6 shows the relationship between uniaxial compressive strength (UCS) and Young's modulus of rock and coal of the GDM underground coal mine. These results were obtained from laboratory tests of the rock and coal samples which were collected from boreholes at different depths. Based on the laboratory test results, the rock and coal in this underground mine are classified into weak/soft and low strength rocks as the UCS values are mostly below 25 $\mathrm{MPa}$ [1], [2].

At GDM underground coal mine, two main roadways namely South and North Roadways are being developed from the final highwall of the old surface mine using the road header machine. Fig. 7 shows the current conditions of the South Roadway development. The roadway is excavated in a semi-circular shape with $5 \mathrm{~m}$ in width and $3 \mathrm{~m}$ in height, with the overburden thickness above the current excavation face is $40 \mathrm{~m}$ approximately. The steel arch of Japan Industrial Standard 3010 (JIS 3010) is selected as the support system for the main roadway. The steel arches with $1 \mathrm{~m}$ space were immediately installed in the roadway just after the excavation face had been moved forward. Based on the field observation inside the main roadway, it is found that the roadway was excavated mostly in the claystone layer, while the roadway excavation in the rock layers between claystone and coal was also observed at some locations. Generally, the roof and sidewalls of the roadway are well maintained by the steel arch support, but because no support is installed in the floor, the floor heave of the main roadway was recognized. However, as the roadway is being excavated at the shallow depth, the heaving of the floor is not a big issue at the GDM coal mine, and it is still easy to overcome. Additionally, water dripping from the roof and sidewalls of the main roadway was observed. As the claystone is very sensitive to the water, the groundwater caused the deterioration in mechanical properties of the claystone, as a result, the large roof displacement of the roadway occurred at some locations.

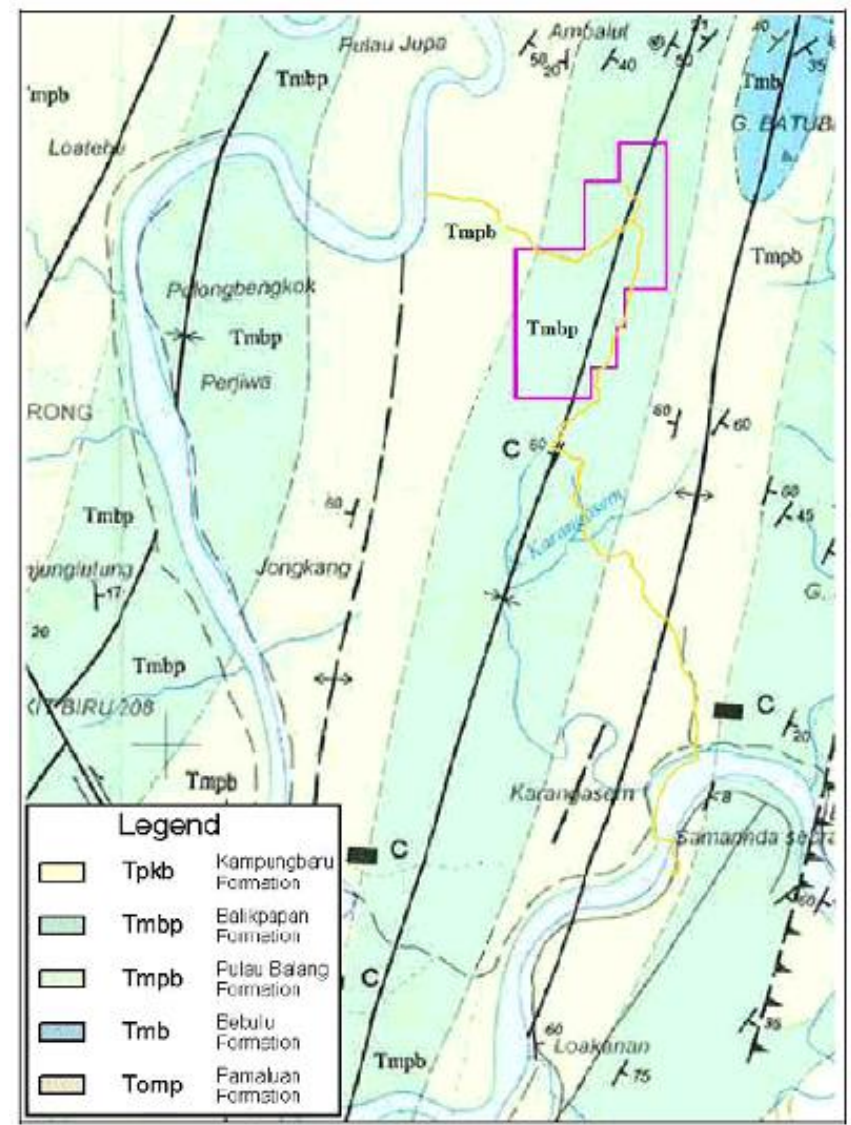

Fig. 4. Geological map of GDM coal mine

In the GDM coal mine, two monitoring systems were applied for detecting the roof movement of the main roadway, including extensometer and telltale. The roof movements measured from these two monitoring systems show that the large roof movement was detected when the roadway excavation was conducted in the deteriorated claystone layer. Differently, the small roof movement was observed when the main roadway was excavated in the undeteriorated claystone, and the coal layer was present in the roof.

Fig. 8 illustrates the measurement data of main roadway displacement obtained from an extensometer monitoring system. Extensometer 31 shows the roof displacement of the roadway excavated in the undeteriorated claystone, whereas Extensometer 29 shows the roof displacement of the roadway 
excavated in the deteriorated claystone, respectively. The displacement of the roof was measured for one month. It was found from the measurement data that although the Extensometer 29 and 31 were installed at the same depth, 40 $m$ depth approximately, the roof displacements obtained from these two locations are obviously different. The roof displacement of about $23 \mathrm{~mm}$ was obtained from Extensometer 31, while the roof displacement of about 83 $\mathrm{mm}$ was obtained from Extensometer 29. The reason for this difference in roof displacement is assumed to be the deterioration of the claystone caused by groundwater. From the results, therefore, it can be said that the geological condition of the claystone has an obvious impact on the stability of the roadway. More attention must be paid to the support design of the main roadway when the excavation is made in deteriorated claystone layer. The roadway near Extensometer 31 could be maintained by the current support system using the steel arch SS400 (yield strength $319 \mathrm{MPa}$ ) with $1 \mathrm{~m}$ space. On the other hand, to maintain the main roadway near the Extensometer 29, the GDM has adopted the stronger steel arch SS540 (yield strength $551 \mathrm{MPa}$ ) and decreased the space of the steel arch from $1 \mathrm{~m}$ to $0.5 \mathrm{~m}$.

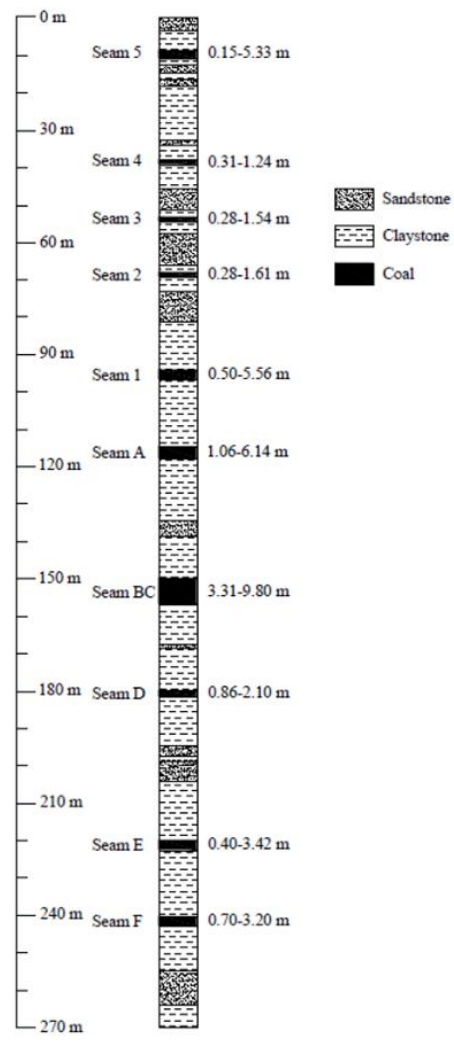

Fig. 5. Stratigraphic column of GDM

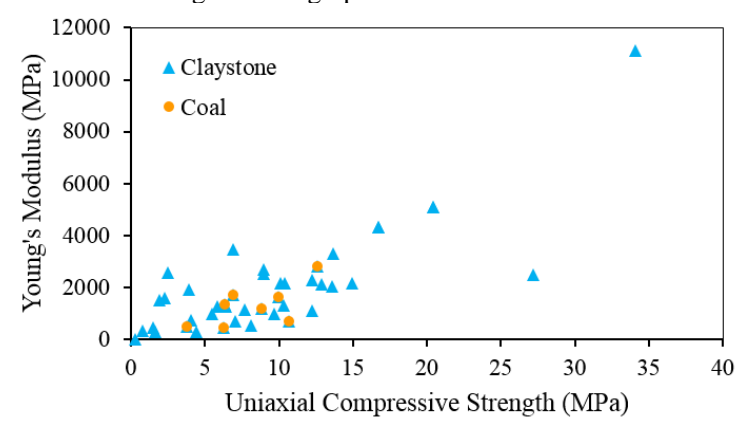

Fig. 6. Relationship between uniaxial compressive strength and Young's modulus of claystone and coal of GDM coal mine.
Fig. 9 demonstrates the results of the Telltale monitoring system of the roof displacement of the roadway under different roof conditions. The measurement data of Telltales 25,29 , and 28 show the roof displacement of the main roadway under the conditions of no coal layer, $0.5 \mathrm{~m}$ thick coal layer, and $1 \mathrm{~m}$ thick coal layer in the roof, respectively. The displacement of the roof was measured for one month. From the measured field data, it is found that the large roof displacement occurred when the roadway was excavated in the claystone layer only. Differently, the small roof displacement occurred when the coal layer was present in the roof. In addition, a smaller displacement of the roof was observed when a thicker coal layer was present in the roof. The total roof displacement obtained from Telltale 25, 29, and 28 was about $90 \mathrm{~mm}, 4.5 \mathrm{~mm}$, and $1.5 \mathrm{~mm}$, respectively. From these trends, it can be considered that the presence and thickness of the coal layer in the roof have an obvious impact on the stability of the main roadway. It is necessary to design the support sufficiently considering each condition.
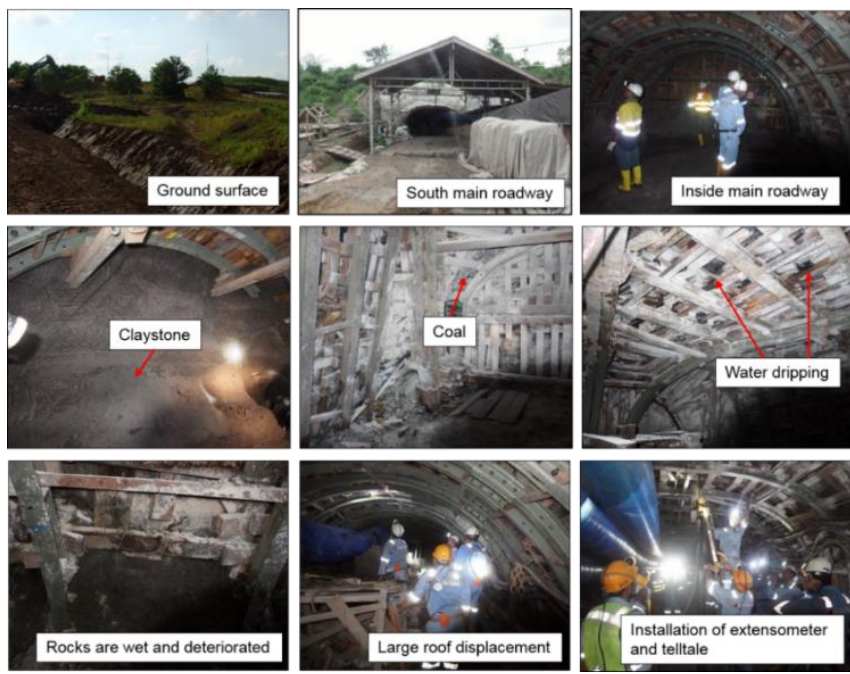

Fig. 7. Current conditions of main roadway development at GDM coal mine.

Based on the field measurement data, it can be found that the stability and ground behavior of the main roadway varies greatly depending on the conditions of claystone and the presence of a coal layer in the roof. It is clear that a large displacement is expected when the roadway excavation is made in a deteriorated claystone and no coal layer is present in the roof. On the contrary, a small displacement is expected when the roadway is excavated in undeteriorated claystone and when a coal layer is present in the roof. To clarify the ground behavior and stability condition of the main roadway according to field measurement data, the paper is aimed to investigate the stability and ground behavior of the roadway under different conditions of claystone and roof. The numerical simulation method using the three-dimensional finite difference code software, FLAC3D was used for clarification. The results of the study will provide a fundamental understanding of the main roadway stability so that mining engineers of the GDM coal mine can use them as the guidelines for determining what geological and excavation conditions that they have to pay more attention to. 


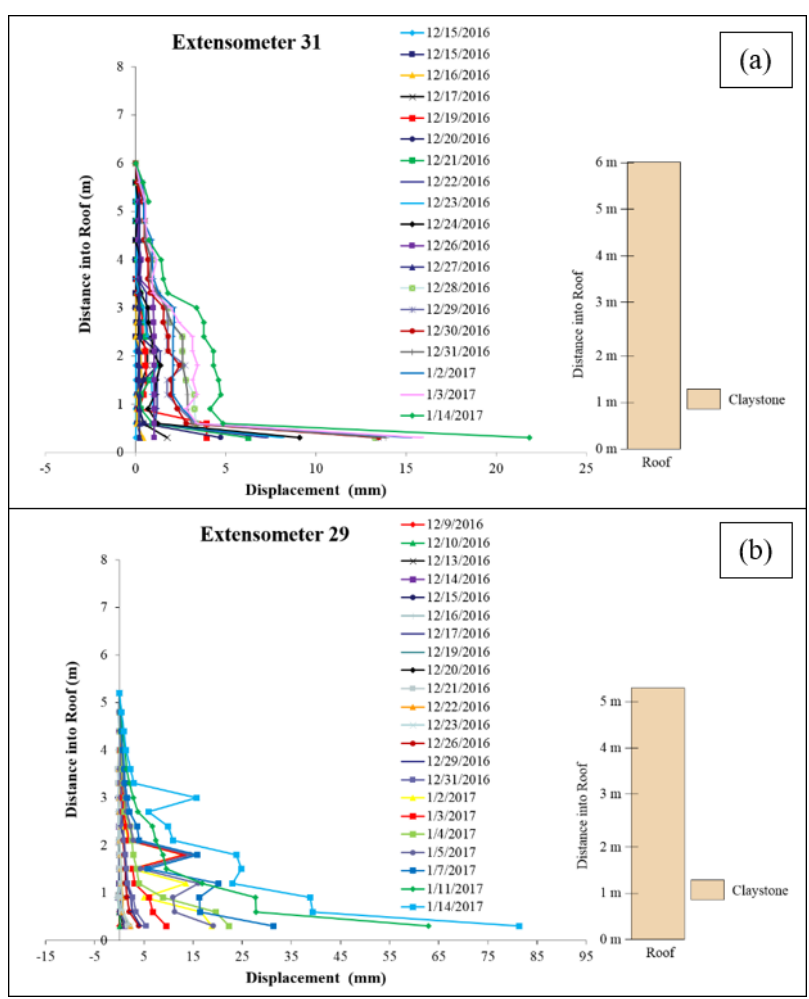

Fig. 8. Comparison of field measurement data of roof displacement between roadway excavations in undeteriorated and deteriorated claystone (a) undeteriorated claystone, (b) deteriorated claystone.

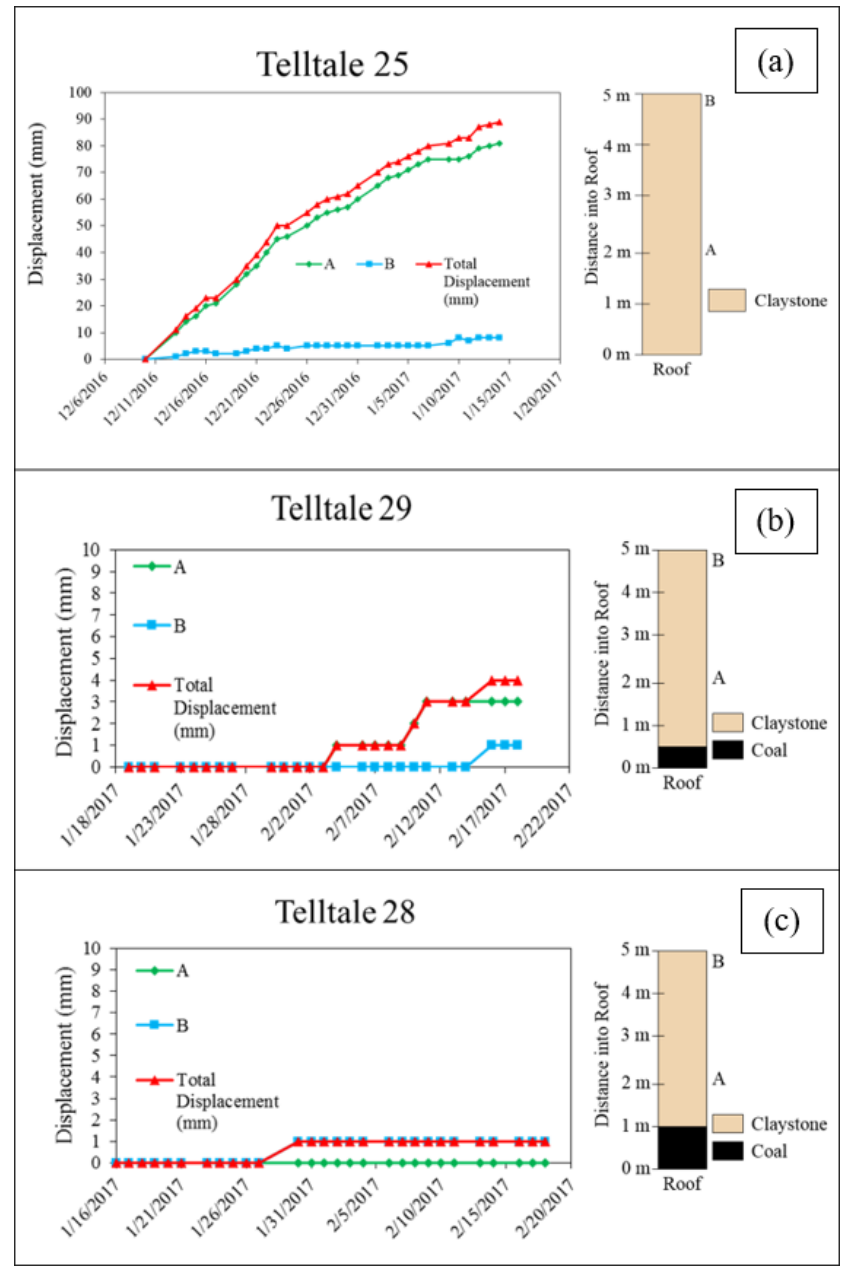

Fig. 9. Telltale measurement data of roof displacement of main roadway under different roof conditions (a) no coal layer in roof, (b) $0.5 \mathrm{~m}$ thick coal layer in roof, (c) $1 \mathrm{~m}$ thick coal layer in roof.

\section{NUMERICAL ANALYSIS}

In order to discuss the stability and ground behavior of the main roadway at the GDM coal mine, several numerical models were conducted in FLAC3D with different overburden depths ranging from $10 \mathrm{~m}$ to $40 \mathrm{~m}$. Fig. 10 demonstrates an example of a numerical model with $40 \mathrm{~m}$ overburden depth. The model is $150 \mathrm{~m}$ in width, $155 \mathrm{~m}$ in length, and $140 \mathrm{~m}$ in height. The model was fixed in the vertical direction at the bottom, fixed in the horizontal direction on the sides, and free in all directions at the surface. The roadway was modeled as semi-circular in shape with $5 \mathrm{~m}$ in width and $3 \mathrm{~m}$ in height. As the steel arch is the primary support system used in this mine, hence, the application of steel arch support for stability control of the main roadway was simulated numerically. According to the UCS values of claystone obtained from this underground coal mine, the rocks near the surface were much weaker than those at the deeper sites due to the weathering. Thus, very weak/soft mechanical properties of claystone were used for the main roadway analysis at the shallow depth. Tables I and II show the mechanical properties of claystone and steel arch, respectively. In the simulation, the vertical stress component was modeled as a function of the overburden thickness, as in (1) [3]-[5], while the horizontal stress was initialized directly through simple gravity loading. The elasto-plastic MohrCoulomb was used as a constitutive model throughout the analyses. In order to obtain the most precise result of the ground behavior around the main roadway, the lateral and vertical meshes were intentionally made finer around the excavation area than the remaining meshes.

$P v=\gamma H$

where $\gamma$ is the unit weight of overburden, $H$ is the overburden depth.

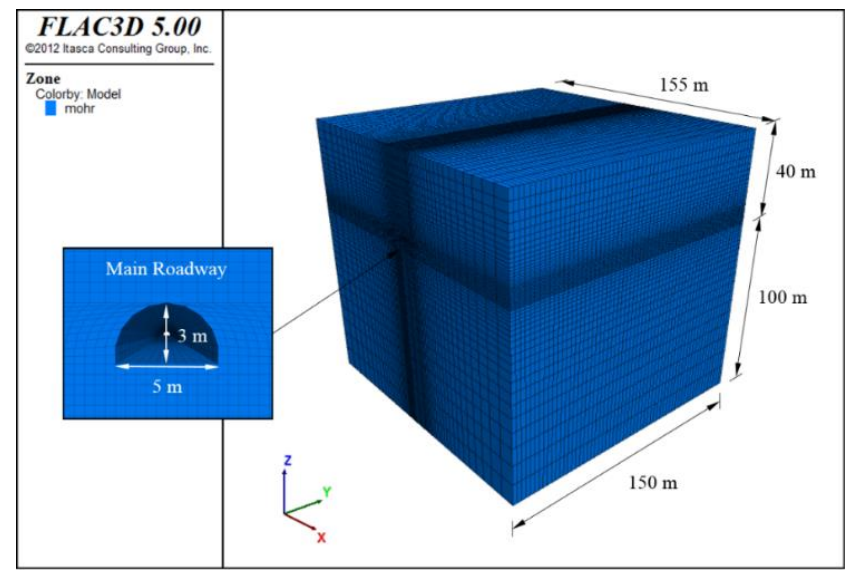

Fig. 10. Numerical model of main roadway analysis under $40 \mathrm{~m}$ overburden depth.

TABLE I: MEChANICAL PRoperties OF Claystone USED IN MAIN ROADWAY STABILITY ANALYSES

\begin{tabular}{cc}
\multicolumn{2}{c}{ ROADWAY STABILITY ANALYSES } \\
\hline \hline Parameter & Value \\
\hline Uniaxial compressive strength $(\mathrm{MPa})$ & 1.12 \\
Density $\left(\mathrm{kg} / \mathrm{m}^{3}\right)$ & 2,140 \\
Young's modulus $(\mathrm{MPa})$ & 118.36 \\
Poisson's ratio & 0.26 \\
Friction angle $\left({ }^{\circ}\right)$ & 29.9 \\
Cohesion $(\mathrm{MPa})$ & 0.14 \\
\hline
\end{tabular}


TABLE II: MECHANICAL PROPERTIES OF STEEL ARCH (JIS 3010) USED IN ANALYSES

\begin{tabular}{cc}
\hline \hline Parameter & Value \\
\hline Dimension $(\mathrm{mm})$ & $95 \times 115$ \\
Cross section area $\left(\mathrm{cm}^{2}\right)$ & 36.51 \\
Young's modulus $(\mathrm{GPa})$ & 200 \\
Poisson's ratio & 0.30 \\
Yield strength, SS400 $(\mathrm{MPa})$ & 319 \\
\hline \hline
\end{tabular}

\section{RESULT AND DISCUSSION}

\section{A. Ground Behavior of Main Roadway under Undeteriorated Claystone Conditions}

Fig. 11 and Fig. 12 show the development of the failure zone and displacement around the main roadway excavated in the undeteriorated claystone under different depths, respectively. Here, the term of failure zone indicates the fractured/failed region induced by the main roadway excavation. This fractured/failed region can potentially fall and create unsafe working conditions for mine workers. The explanations of failure zones given in the legend in FLAC3D are as follows: "none" indicates no-failure zone, "shear-n" indicates the region failed under shear loading, and failure process is still in progress, "shear-p indicates the region failed under shear loading, and failure process is stopped due to lowered amount of shear forces, "tension- $n$ " indicates the region failed under tensile loading, and failure process is still in progress, and the last is "tension-p indicates the region failed under tensile loading, and failure process is stopped due to lowered amount of tensile forces [6]. According to both Fig. 11 and Fig. 12, it can be seen that the overburden depth affected the development of the failure zone and displacement. Under unsupported conditions, the failure zone and displacement increased with increasing the overburden depth. This happened because of the increase of the in-situ stress as the overburden thickness increased. The roadway at a deeper depth will require higher support capacity. Nonetheless, after the roadway was maintained by steel arch SS400 with $1 \mathrm{~m}$ space, the failure zone and displacement were reduced significantly. It can be said that the current support system works well to control the failure zone and displacement of the roadway under undeteriorated conditions of claystone.

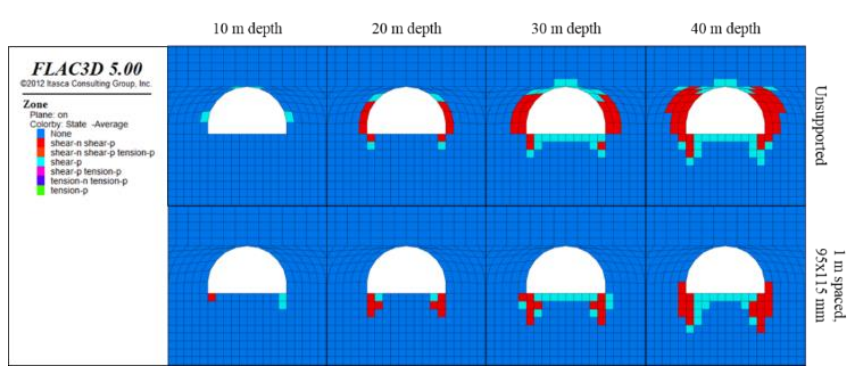

Fig. 11. Failure zone around the main roadway under different overburden depths.

Fig. 13 shows a comparison between numerical simulation results and field measurement data of the roadway displacement. The comparison was made in the case of the roadway excavation in the undeteriorated claystone under 40 $m$ depth, and the roadway was supported by steel arches with $1 \mathrm{~m}$ space. From these figures, it can be seen that the stability and ground behavior of the main roadway was well simulated. The simulated results are in good agreement with the field measurement data. The roof displacement obtained from both methods occurred largely near the roofline, and it was gradually decreased with increasing the distance into the roof. Therefore, it can be said that the numerical simulation method using finite difference code FLAC3D is capable to study the stability and ground behavior of the roadway in the GDM underground coal mine.

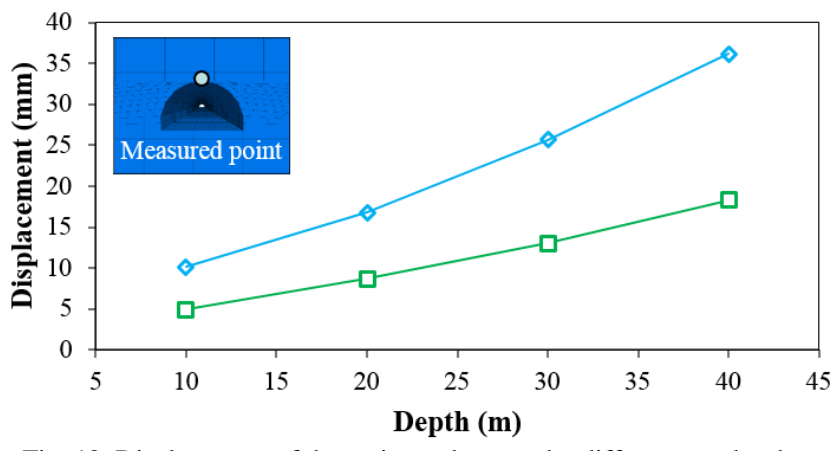

Fig. 12. Displacement of the main roadway under different overburden depths.

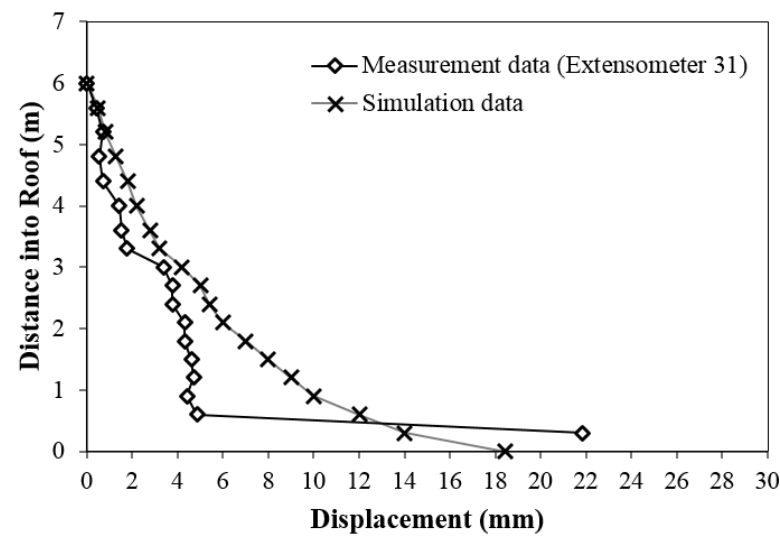

Fig. 13. Comparison of field measurement data and simulation results of main roadway displacement.

As a steel arch is the support system applied to stabilize the main roadway at the GDM coal mine, the stress occurring on the steel arch is apparently caused by the roadway excavation. Hence, analysis of the steel arch axial stress can be a proper method for evaluating the stability of the main roadway. The definition of the steel arch axial stress is given as the stress which is accumulated in the steel arch axially due to acted forces induced by the excavation. If it exceeds the maximum yield strength of the steel arch, the steel arch may start to deform. Fig. 14 shows the simulated results of steel arch axial stress of the support installed in the roadway. From this figure, when the roadway was excavated in undeteriorated claystone, the steel arch SS400 support with $1 \mathrm{~m}$ space could only stabilize the main roadway until $35 \mathrm{~m}$ depth, and it will be difficult to maintain the roadway at a deeper depth. An application of a closer spaced steel arch $(0.5 \mathrm{~m}$ space) was investigated. It was found that the steel arch SS400 with 0.5 $\mathrm{m}$ space could stabilize the roadway deeper than $40 \mathrm{~m}$ depth. This indicates that a decrease in steel arch space significantly improves the stability of the main roadway. 


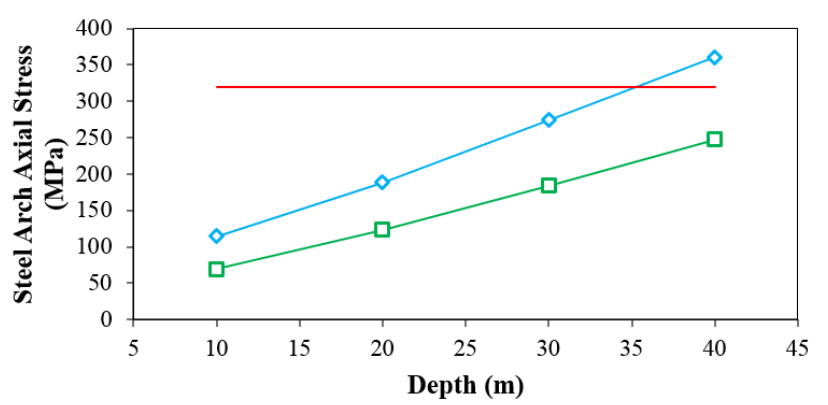

$\neg-$ Undeteriorated claystone $-1 \mathrm{~m}$ spaced steel arch,95x115 mm

$-\square$-Undeteriorated claystone $-0.5 \mathrm{~m}$ spaced steel arch, $95 \times 115 \mathrm{~mm}$

- Maximum yield strength of steel arch-SS400

Fig. 14. Simulated results of steel arch axial stress for main roadway excavation under undeteriorated claystone conditions.

\section{B. Ground Behavior of Main Roadway under Deteriorated Claystone Conditions}

As a great deal of the groundwater was observed inside the roadway, the mechanical properties of claystone are prone to deterioration due to water. The failure zone and displacement may expand considerably. To investigate the ground behavior of the main roadway under this condition, hence, (2) and (3) were used in the analyses in order to understand the deterioration in the mechanical properties of claystone caused by groundwater [7]. The properties of deteriorated claystone are summarized in Table III.

$S_{c}{ }^{\prime}=0.386 S_{c}$

$E^{\prime}=0.144 E$

where

$S_{c}$ is uniaxial compressive strength under dry conditions;

$S_{c}$ ' is uniaxial compressive strength after curing in water;

$E$ is Young's modulus under dry conditions;

$E$ ' is Young's modulus after curing in water.

TABLE III: MECHANICAL PROPERTIES OF DETERIORATED CLAYSTONE USED IN ANALYSES

\begin{tabular}{cc}
\hline \hline Parameter & Value \\
\hline Uniaxial compressive strength $(\mathrm{MPa})$ & 0.43 \\
Density $\left(\mathrm{kg} / \mathrm{m}^{3}\right)$ & 2,160 \\
Young's modulus $(\mathrm{MPa})$ & 17.04 \\
Poisson's ratio & 0.26 \\
Friction angle $\left({ }^{\circ}\right)$ & 25.9 \\
Cohesion $(\mathrm{MPa})$ & 0.10 \\
\hline \hline
\end{tabular}

Fig. 15 and Fig. 16 illustrate the development of failure zone and displacement of the roadway by taking the deterioration of claystone due to groundwater into account. The roadway was supported by $1 \mathrm{~m}$ spaced steel arches in the simulations. Compared with the roadway excavated in undeteriorated claystone layer, the failure zone and displacement expanded dramatically. Under $40 \mathrm{~m}$ depth, the displacement increased largely from $18.29 \mathrm{~mm}$ to $116.43 \mathrm{~mm}$. It is indicated that the current support system may not work effectively, and the collapse of roof and sidewalls can potentially happen in this situation. According to the field measurement data of the roof displacement of the main roadway excavated under undeteriorated and deteriorated claystone conditions (Fig. 8), the measured field data support the numerical simulation results. The similar thing happened in the field as that resulted in the simulation. Therefore, it can be said that the mechanical conditions of claystone have a significant impact on the stability of the main roadway, more attention must be paid on the stability control of the roadway when the excavation is made in deteriorated claystone layer. The deterioration of the claystone due to water can be controlled by the introduction of an appropriate drainage system. By applying drainage system, the stability of the roadway will be maintained in a better condition. Moreover, in order to improve the stability of the roadway under deteriorated conditions of claystone, the modification of the support system must be made. The steel arch with closer space ( $0.5 \mathrm{~m}$ space) should be installed, or a stronger steel arch support (steel arch SS540, yield strength $551 \mathrm{MPa}$ ) should be applied. However, these improvements of support system can be very costly. On the other hand, in the case where the large roof displacement occurs continuously, it may be hard to stop the movement although the improvement of support system has been done. Under this condition, the deformed part of the roadway must be excavated and removed, and the support must be reinstalled. The activities will be repeated once the large displacement occurs. However, this method may be good for the economical point of view in term of support system, but it can disturb the production rate of the mine as it needs times to complete such those activities.

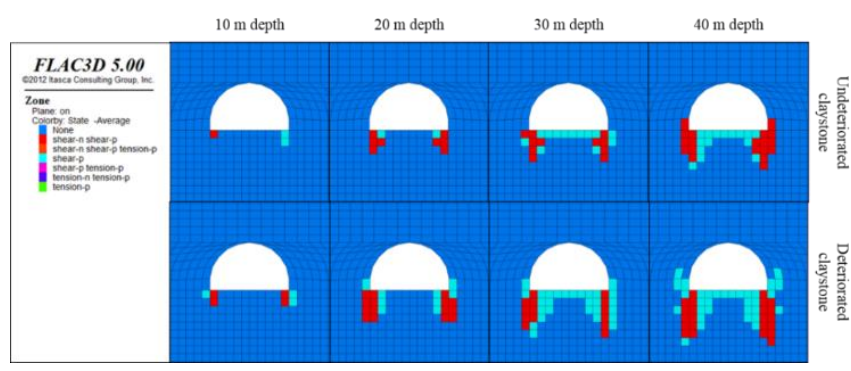

Fig. 15. Comparison of failure zones between roadway excavations in undeteriorated and deteriorated claystone.

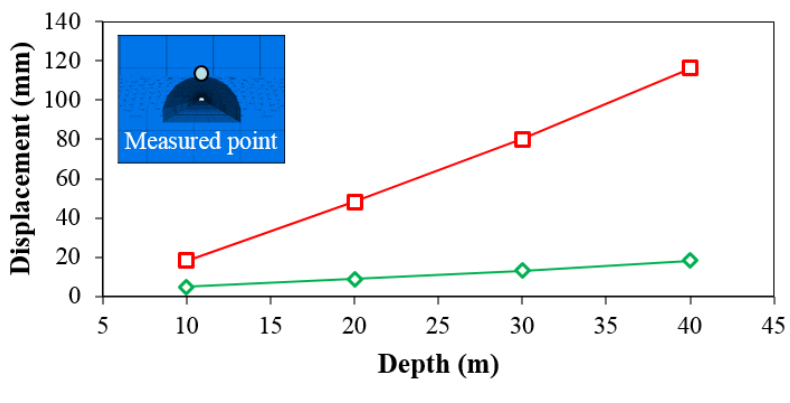

$\multimap$ Undeteriorated claystone $\quad-\square$-Deteriorated claystone

Fig. 16. Comparison of roof displacements between roadway excavations in undeteriorated and deteriorated claystone.

Fig. 17 shows the simulated results of steel arch axial stress of the support installed in the roadway. From this figure, when the roadway excavation was made in deteriorated claystone, it would be very hard to control the roadway stability by the steel arch SS400. The steel arch SS400 could only maintain the roadway until $28 \mathrm{~m}$ depth although the 0.5 $\mathrm{m}$ space was adopted. This indicates that a stronger steel arch must be applied in this situation. As shown in the figure below, after stronger steel arch SS540 was used, the roadway 
stability could be maintained until $27 \mathrm{~m}$ depth by $1 \mathrm{~m}$ space, while it was able to maintain deeper than $40 \mathrm{~m}$ depth by 0.5 $\mathrm{m}$ space. Recently, to increase the stability of the roadway, and to ensure the safety of mine workers, the GDM coal mine has already adopted the steel arch SS540 for main roadway support. It works effectively at present.

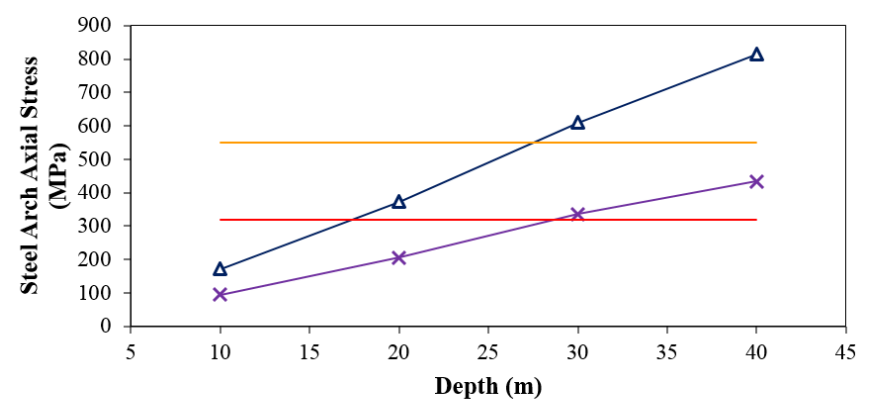

$\triangle-$ Deteriorated claystone -1 $\mathrm{m}$ spaced steel arch,95x115 mm

$\rightarrow$ Deteriorated claystone $-0.5 \mathrm{~m}$ spaced steel arch,95x115 mm

— Maximum yield strength of steel arch-SS400

— Maximum yield strength of steel arch-SS540

Fig. 17. Simulated results of steel arch axial stress for main roadway excavation under deteriorated claystone conditions.

\section{Ground Behavior of Main Roadway under Different Roof Conditions}

As described previously according to the field observation, the roadway at the GDM coal mine has been excavated not only in claystone, but also in the rock layers between claystone and coal at some locations. This indicates that the immediate roof does not only consist of the claystone, but also the coal. Under this condition, as the coal is stronger than the claystone, the ground behavior of the roadway may be different from the one excavated in claystone only. In this section, the stability and ground behavior of the main roadway under different roof conditions was investigated by means of numerical simulations. Three roof conditions were simulated numerically as shown in Fig. 18. The first condition is the roadway excavation in a claystone layer. The second condition is the roadway excavation in the layers of claystone and coal with the presence of a $1 \mathrm{~m}$ thick coal layer in the roof. The last case is the roadway excavation in the rock layers of claystone and coal with the presence of a $0.5 \mathrm{~m}$ thick coal layer in the roof. In the simulation, the roadway was supported by $1 \mathrm{~m}$ spaced steel arches. Table IV describes the mechanical properties of claystone and coal used in the analyses.

TABLE IV: MEChANICAL PROPERTIES OF ClAYSTONE AND COAL USED IN ANALYSES UNDER DIFFERENT ROOF CONDITIONS

\begin{tabular}{ccc}
\multicolumn{2}{c}{ ANALYSES UNDER DIFFERENT ROOF CONDITIONS } & \\
\hline \hline Parameter & $\begin{array}{c}\text { Claystone } \\
\text { (deteriorated) }\end{array}$ & Coal \\
\hline Uniaxial compressive strength $(\mathrm{MPa})$ & 0.43 & 8.16 \\
Density $\left(\mathrm{kg} / \mathrm{m}^{3}\right)$ & 2,160 & 1,380 \\
Young's modulus $(\mathrm{MPa})$ & 17.04 & 1,296 \\
Poisson's ratio & 0.26 & 0.25 \\
Friction angle $\left({ }^{\circ}\right)$ & 25.9 & 45.7 \\
Cohesion $^{(\mathrm{MPa})}$ & 0.10 & 2.63 \\
\hline \hline
\end{tabular}
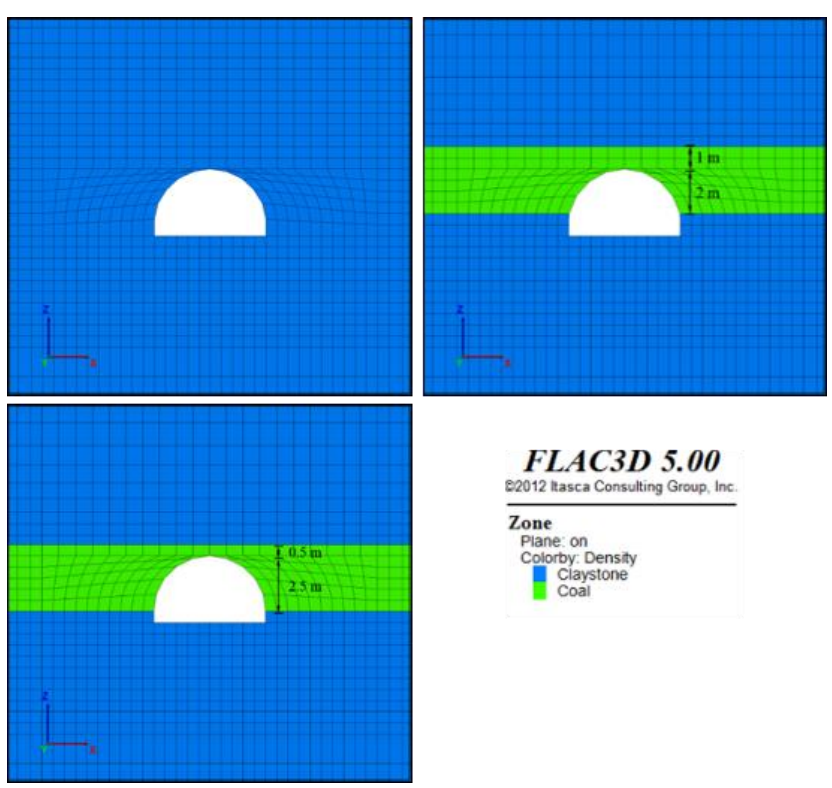

Fig. 18. Numerical models for ground behavior analysis of the main roadway under various roof conditions.

Fig. 19 illustrates the analyzed results of roadway displacement under different roof conditions. The results show that the largest displacement occurred when the roadway was excavated in claystone only. The decrement of displacement was observed with the presence of the coal layer during the roadway excavation. This happened due to the strength effect of the coal layer. As the coal is stronger than the claystone, it was more able to bridge over the roadway opening, resulted in smaller displacement. The results also indicate that a decrease in roadway displacement was significantly associated with the thickness of a coal layer in the roof. The roadway excavation with the presence of a $1 \mathrm{~m}$ thick coal layer in the roof produced smaller displacement compared with the ones that had $0.5 \mathrm{~m}$ and had no coal layer in the roof, respectively. This is because of the thickness effect of a coal layer left in the roof. A thicker coal layer has more ability to bridge across the roadway opening and results in smaller displacement. According to the measurement data of the roof displacement of the roadway excavated under different roof conditions (Fig. 9), the measured field data of roadway displacement support the results of numerical simulations. Very large roof displacement was obtained where the roadway was excavated in claystone only. The displacement was decreased apparently with the presence of a coal layer in the roof, and its decrement significantly depended on the thickness of the coal in the roof. From these trends, it can be said that the presence of a coal layer during the excavation considerably improves the stability of the main roadway. By leaving a thicker coal layer in the roof, a better stability condition of the roadway can be achieved. The knowledge learned from the simulation results and field measurement data in this research is beneficial not only to the roadway stability at the shallow depth, but also to the stability of main and gate roadways at the deep depth when the longwall mining starts. Since the main and gate roadways will be developed inside the coal seam, some parts of the coal can be left in the roof and floor in order to increase the stability of the roadways. 


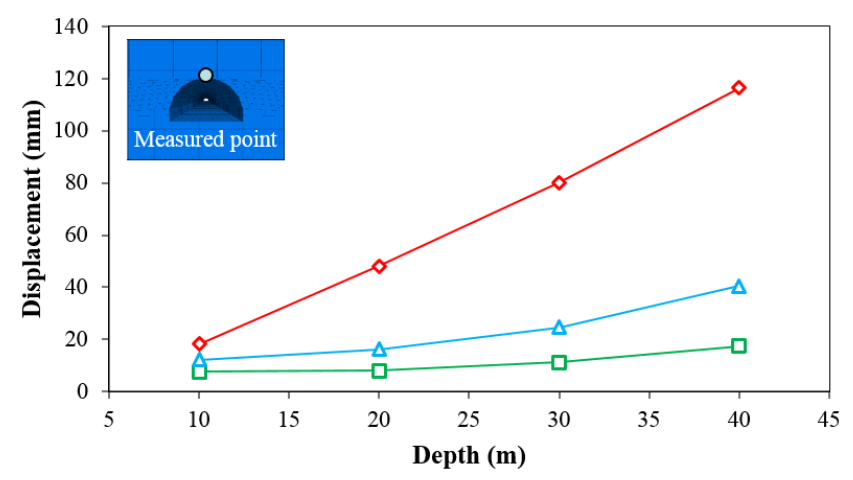

$\smile$ Main roadway excavated inside claystone (deteriorated)

$-\square-$ Main roadway excavated inside claystone and coal-1 $\mathrm{m}$ coal layer in roof

$\triangle-$ Main roadway excavated inside claystone and coal-0.5 $\mathrm{m}$ coal layer in roof

Fig. 19. Displacement of the main roadway under different roof conditions.

\section{CONCLUSION}

The conditions of GDM underground coal mine are described in this research. The GDM coal mine is a new underground coal mine and is still in the process of developing the main roadways. Based on the laboratory test results, the rocks of this underground coal mine are classified into very weak/soft and low strength rock mass. The ground behavior of the main roadway is also discussed based on field measurement data and numerical simulation results. According to the field measurement data, it is found that the mechanical conditions of claystone and the geological conditions of the roof have an obvious impact on the stability of the main roadway. The large roof displacement of the roadway occurs when the roadway is excavated in the deteriorated claystone, whereas the small roof displacement occurs when the roadway excavation is made in the undeteriorated claystone and when the coal layer is present in the roof.

To clarify the ground behavior of the main roadway based on the field measurement data, the numerical simulation method using FLAC3D software is used as a tool for clarification. The simulation results are then compared with the measurement data for verification. From the comparisons, it is found that they are in good agreement, the simulation results support the field measurement data. Under undeteriorated conditions of claystone, the small failure zone and displacement of the roadway occur. The current support system using the steel arch SS400 is effective to control the roadway stability. As the claystone has deteriorated due to groundwater, the failure zone and displacement expand considerably, and the roadway stability decreases significantly. The use of the current support system (steel arch SS400) is difficult to control the stability of the main roadway. Under this situation, a stronger steel arch SS540 is recommended to apply. Furthermore, the presence of a coal layer during the excavation considerably improves the stability of the main roadway. Compared with the roadway excavated in claystone only, the displacement decreases significantly. In addition, by leaving a thicker coal layer in the roof, a better stability condition of the roadway can be achieved.

Currently, the roadways at the GDM coal mine are maintained in a stable condition at the shallow depth by steel arch support. However, the stability condition and the support system of the roadway at the deep area are still unknown, and they must be studied before starting a longwall mining operation.

\section{ACKNOWLEDGMENT}

The authors are grateful to the PT Gerbang Daya Mandiri underground coal mine for providing the data used in the analyses. Phanthoudeth Pongpanya also wishes to express his special thanks to the AUN-SEED/Net, JICA for the financial support for conducting this research at Kyushu University, Japan.

\section{REFERENCES}

[1] Z. T. Bieniawski, "Estimating the strength of rock masterials," International Journal of the South African Institute of Mining and Metallurgy, vol. 74, no. 8, pp. 312-320, 1974. Available: https://www.saimm.co.za/Journal/v074n08p312.pdf.

[2] E. Hoek and E. T. Brown, "Practical estimates of rock mass strength," International Journal of Rock Mechanics and Mining Sciences, vol. 34, no. $8, \quad$ pp. 1165-1186, 1997. Available: https://www.rocscience.com/assets/resources/learning/hoek/1997Practical-Estimates-of-Rock-Mass-Strength.pdf.

[3] E. Hoek and E. T. Brown. Underground excavations in rock. London, UK.: CRC Press, 1980.

[4] E. Hoek, P. K. Kaiser and W. F. Bawden. Support of underground excavations in hard rock. West Btunnel Professional Centre, Vancouver, British Columbia: Tayley and Francis, 1993, ch. 7, pp. 7173.

[5] E. Hoek, Practice rock engineering. North Vancouver, B. C., Canada:V7R 4X1, 2006, ch. In situ and induced stresses, pp. 1-3, 2006.

[6] N. E. Yasitli and B. Unver, "3D numerical modeling of longwall mining with top-coal caving," International Journal of Rock Mechanics and Mining Sciences, vol. 42, no. 2, pp. 219-235, 2005. Available: https://doi.org/10.1016/j.ijrmms.2004.08.007.

[7] M. Ichinose, K. Uchino and K. Matsui, "Slaking properties of coal measure rocks: A study on the effect of water content on mechnical properties of coal measure rocks," MMIJ (in Japanese), 1989.

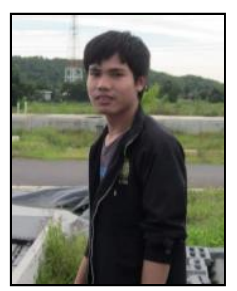

Phanthoudeth Pongpanya has received his doctoral degree in Earth Resources Engineering from Kyushu University, Japan in 2018. At present, he is a young teaching staff at the Department of Mining Engineering, Faculty of Engineering, National University of Laos, Lao PDR. His research interests are in the field of mining engineering, engineering geology and civil engineering. He has published research papers in both local and international peer reviewed journals.

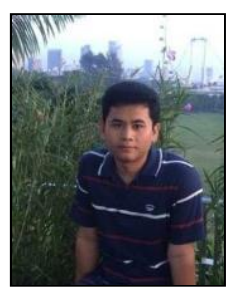

Vongsavanh Soysouvanh has received a master degree in Geological Engineering from Gadjah Mada University, Yogyakarta, Indonesia in 2008. At present, he is a Head of Mining Engineering Division at the Department of Mining Engineering, Faculty of Engineering, National University of Laos, Lao PDR. His research interests are in the field of mining engineering and engineering geology.

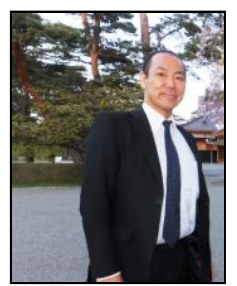

Takashi Sasaoka is an Associate Professor at the Rock Engineering and Mining Machinery Laboratory, Department of Earth Resources Engineering, Faculty of Engineering, Kyushu University, Japan. He has engaged in various projects on ground control issues in underground and surface mines, highwall mining system, controlled blasting and rock cutting. 
Hideki Shimada is a Professor at the Rock Engineering and Mining Machinery Laboratory, Department of Earth Resources Engineering, Faculty of Engineering, Kyushu University, Japan. $\mathrm{He}$ is specialized in rock engineering, pipe jacking, and ground control issue in underground and surface mines. 